SABINA REJMAN

https://orcid.org/0000-0002-4863-6943

Uniwersytet Rzeszowski

\title{
PRÓBY OŻYWIENIA AKTYWNOŚCI SPOŁECZNO-POLITYCZNEJ MIESZKAŃCÓW MIAST W DOBIE AUTONOMII GALICYJSKIEJ (NA PRZYKÆADZIE „MIESZCZANINA”)
}

Zarys treści: Wiek XIX to czas zastępowania feudalnej struktury społecznej nowym porządkiem kapitalistycznym. Zmianom towarzyszyło powstawanie partii politycznych reprezentujacych ruchy społeczno-polityczne. „Mieszczanin" - pismo wydawane w latach 1894-1908 (z przerwami) w Nowym Saczu - za cel postawiło sobie aktywizację polityczną i społeczną mieszczaństwa oraz utworzenie stronnictwa mieszczańskiego, które reprezentowałoby interesy tej grupy społecznej. Artykuł ma odpowiedzieć na pytanie, w jakim stopniu zamierzenie to udało się zrealizować.

The content outline: The nineteenth century saw the transformation of the societal structure from the feudal model to capitalism. These changes were accompanied by the formation of political parties representing various socio- political movements. The Mieszczanin, a magazine published in Nowy Sacz in the years 1894-1908 (with interruptions), sought to spark political and social activation of the bourgeoise and to form a bourgeois party which would represent the interests of this particular social group. The article aims to analyze the extent to which the goal of the magazine was achieved.

Słowa kluczowe: Galicja, miasta, autonomia, prasa, „Mieszczanin”

Keywords: Galicia, towns, autonomy, press, Mieszczanin

\section{Wstęp}

Przemiany polityczne, społeczne i gospodarcze zapoczątkowane na przełomie XVIII i XIX w. zachwiały podstawami starego układu feudalnego w Europie. Rodził się nowy, kapitalistyczny porządek, ale mimo 
odmiennych warunków, w których się kształtował, nie zrywał całkowicie z istniejącym wcześniej. Pozycji w hierarchii społecznej nie wyznaczało już tylko urodzenie, ale przede wszystkim stan posiadania i wykształcenie, aczkolwiek szlacheckie korzenie były pożądanym uzupełnieniem i uzasadnieniem wysokiego miejsca zajmowanego w społeczeństwie. Stare stany (szlachta, chłopi, duchowieństwo) ewoluowały, powstawały też nowe grupy społeczne (burżuazja, robotnicy, inteligencja), szukające swojego miejsca w zmieniającym się świecie. Kłopoty z własną tożsamością miało mieszczaństwo.

Historia społeczna ziem polskich ma bogata literaturę. Fundamentalna pozycja jest Społeczeństwo polskie od $X$ do XX wieku autorstwa Ireneusza Ihnatowicza, Antoniego Mączaka, Benedykta Zientary i Janusza Żarnowskiego (pierwsze wydanie z 1979 r., ostatnie, piąte, z 2005 r. $)^{1}$. Bardziej szczegółowe spojrzenie przynosi seria Społeczeństwo polskie XVIII i XIX wieku wydawana pod redakcja Witolda Kuli i Janiny Leskiewiczowej. Z punktu widzenia problematyki podejmowanej $\mathrm{w}$ tym artykule istotne są opracowania dotyczące inteligencji i urzędników w Galicji ${ }^{2}$. Historii społecznej i przemianom społecznym w późniejszym okresie, jak również metodologii historii społecznej wiele uwagi poświęcił Janusz Żarnowski³ (zob. zwłaszcza serię Metamorfozy Społeczne). Zagadnienia te podejmowali także inni autorzy, a ich perspektywy obserwacyjne przydawały badaniom charakteru interdyscyplinarnego ${ }^{4}$. Zagadnieniom miast i miasteczek galicyjskich oraz zamieszkującym ich społecznościom wiele uwagi poświęciła Jadwiga Hoff 5 .

${ }^{1}$ I. Ihnatowicz, A. Mączak, B. Zientara, J. Żarnowski, Społeczeństwo polskie od X do XX wieku, wyd. 5, Warszawa 2005.

${ }^{2}$ I. Homola, Inteligencja galicyjska $w$ połowie XIX w. Próba charakterystyki, w: Spoteczeństwo polskie XVIII i XIX wieku. Studia o uwarstwieniu i ruchliwości społecznej, t. 6, red. J. Leskiewiczowa, Warszawa 1974, s. 101-139; I. Ihnatowicz, Urzędnicy galicyjscy $w$ dobie autonomii, w: tamże, s. 205-223.

3 J. Żarnowski, Społeczeństwa XX wieku, Wrocław 1999; tenże, Historia społeczna. Metodologia, ewolucja, perspektywy, Warszawa 2011 (Metamorfozy Społeczne, 3).

${ }^{4}$ W. Kwaśniewicz, Między modelem agrarnym a postindustrialnym. Przeobrażenia społeczeństwa polskiego w XX wieku, w: Polska i Polacy w XIX-XX wieku. Studia ofiarowane Profesorowi Mariuszowi Kulczykowskiemu w 70. rocznice jego urodzin, red. K. Ślusarek, Kraków 2002, s. 135-145.

5 J. Hoff, Mieszkańcy małych miast Galicji Wschodniej w okresie autonomicznym, Rzeszów 2005; taż, Spoteczność matego miasta galicyjskiego w dobie autonomii, Rzeszów 1992; taż, Życie społeczne $w$ małych miastach Galicji Zachodniej w dobie autonomii, w: Galicja i jej dziedzictwo, t. 2: Społeczeństwo i gospodarka, red. J. Chłopecki, H. Madurowicz-Urbańska, Rzeszów 1995, s. 223-234; taż, Żydzi, Polacy i Rusini w matych miastach Galicji Wschodniej w drugiej połowie XIX w. Sqsiedzi, obcy, wrogowie?, 
W Galicji szczególnie widoczny był kryzys, który w XIX i na początku XX w. przeżywały miasta i mieszczaństwo, ponieważ ani stare mieszczaństwo, ani nowe grupy z nim powiązane nie miały silnej pozycji. W miastach dominowało drobnomieszczaństwo, które cechował konserwatyzm poglądów oraz religijność, często bezrefleksyjna. Liczna była inteligencja. Burżuazja była mało znacząca siła, wyrosła na bazie kapitału ziemiańskiego i obcego w ośrodkach przemysłowych (zagłębie naftowe wokół Borysławia i Drohobycza, zakłady przemysłowe średniej wielkości w Krakowie i Zagłębiu Krakowskim, Śląsk Cieszyński). Tam, gdzie przemysł był rozwinięty, kształtowała się klasa robotnicza, rekrutująca się ze zrujnowanych rzemieślników i chłopów przybyłych ze wsi. Ci, którzy nie zdołali się odnaleźć w nowych warunkach, zasilali lumpenproletariat lub margines społeczny ${ }^{6}$.

Wraz z nowym układem sił społecznych powstawały nowe ugrupowania polityczne, które zarazem aktywnie uczestniczyły w jego formowaniu. W czasie Wiosny Ludów ukształtował się obóz konserwatywno-ziemiański oraz liberalno-mieszczański. Po zniesieniu pańszczyzny rodził się i rósł w siłę ruch ludowy. Rozwijał się także ruch socjalistyczny i narodowy?

W obliczu przemian społecznych, wobec powstających partii i ich organów prasowych, zauważalny jest brak nurtu obejmującego swoim wpływem mieszczaństwo. Witold Lewicki pisał w 1891 r.: „U nas nawet w ciaśniejszym kole wewnętrznego życia miejskiego nie wytworzono tego co to życie cechować powinno - prawdziwego mieszczaństwa. [...] Może [...] inteligencya łącząc się z rdzennem sławetnem mieszczeństwem, do naprawienia wielu błędów i do ożywczej pracy [...] wspólnym wysiłkiem się zabierze"s.

Nie dziwi zatem, że na rynku prasowym pojawiło się czasopismo, które za cel stawiało sobie podniesienie poziomu świadomości społecznej i politycznej tej grupy, czego wyrazem miało być doprowadzenie do formalnego ukonstytuowania się ruchu mieszczańskiego. „Mieszczanin” wkroczył na scenę dziejową 1 X 1894 r., kiedy w Nowym Sączu ukazał

w: Społeczeństwo w dobie przemian: wiek XIX $i$ XX. Księga jubileuszowa Profesor Anny Żarnowskiej, red. M. Nietyksza i in., Warszawa 2003, s. 337-344.

${ }^{6}$ Kłopot z przynależnością pojawiał się w odniesieniu do urzędników prywatnych, urzędników kolejowych, techników i inżynierów; zob. I. Ihnatowicz, Społeczeństwo polskie 1864-1914, Warszawa 1988, s. 23-48.

7 Z. Fras, Galicja, Wrocław 2000, s. 163, 191-195; T.A. Kisielewski; Pitsudski, Dmowski i niepodległość. Osobno, ale razem, Poznań 2018, s. 22-23.

8 W. Lewicki, Organizacja gmin miejskich w Galicji, „Ekonomista Polski” 5, 1891, s. 55 . 
się pierwszy numer pisma, określonego jako „dwutygodnik polityczny, ekonomiczny i społeczny, organ miast mniejszych i miasteczek".

\section{Nowy Sącz i wydawane tam czasopisma}

„Mieszczanin” był jednym z wielu czasopism powstałych wówczas na fali ożywienia politycznego i społecznego oraz większych możliwości wydawniczych, które stopniowo dawała Galicji autonomia. Nowy Sącz w latach 1868-1915 był ważnym lokalnym ośrodkiem wydawniczym, w którym według Jerzego Łojka wydawano 19 tytułów prasowych, a zdaniem Jerzego Jarowieckiego i Jacka Lachendry - 299. Pierwszym czasopismem, które zagościło tu na dłużej (1891-1913, z przerwami), było „Szkolnictwo Ludowe”, organ prasowy nauczycieli szkół ludowych. Kolejne tytuły prasowe to: „Zwiazek Chłopski” (pierwszy numer z 1 III 1894 r.), „Mieszczanin” (od 1 X 1894 do 31 XII 1908 r., z przerwami), „Sądeczanin” (1900-1903, przeją program czasowo zawieszonego „Mieszczanina”), „Głos z Nowego Sacza” (1902, pismo nowosądeckiego magistratu), „Gazeta Sądecka” (1909), „Ziemia Sądecka” (1913-1914, według Kazimierza Golachowskiego „najlepiej dotąd redagowane czasopismo”) oraz inne, których żywot przeważnie był krótki ${ }^{10}$.

Dane te odzwierciedlają aspiracje miasta, które wykorzystało szansę, jaka dało mu włączenie w sieć linii kolejowych - w 1876 r. otwarta została linia tarnowsko-leluchowska i do Nowego Sacza wjechał pierwszy pociag, natomiast w 1884 r. zakończono budowę Galicyjskiej Kolei Transwersalnej, która również miała tu przystanek. W 1876 r. obok stacji założono Warsztaty Kolei. To wokół nich powstała zwarta grupa zawodowa kolejarzy, która wyraźnie zaznaczała swoją obecność w życiu miasta. Od 1889 r. Nowy Sacz podlegał ustawie gminnej ustanowionej dla 30 większych miast w Galicji. Miały tutaj swoją siedzibą instytucje rządowe i samorządowe. W mieście stacjonowało wojsko, dla którego wybudowano koszary i urządzono szpital wojskowy. Powstawały banki, kasy oszczędnościowo-zapomogowe, kolejne apteki, pomniki. Rozwijało się szkolnictwo, najstarsze cesarsko-królewskie gimnazjum w Nowym Sączu działało od 1819 r., powstawały też nowe szkoły. Istotne znaczenie

9 J. Jarowiecki, Ksztattowanie się środowiska prasowego Nowego Sacza i regionu, w: Prasa sqdecka od zarania do dziś 1891-2011, red. B. Faron, współpr. A. Ogonowska, Kraków 2012, s. 13; J. Lachendro, Prasa województwa krakowskiego w latach 1918-1939, Kraków 2006, s. 61.

${ }^{10}$ K. Golachowski, Dzieje prasy nowosqdeckiej (1891-1961), „Rocznik Sądecki” 5, 1962 , s. $225-270$, cyt. ze s. 249. 
miał też klasztor oo. Jezuitów, którzy pojawili się w mieście w $1832 \mathrm{r}$. i pozostawali w nim, wyjąwszy czas banicji (1848-1853). Rozwój życia społecznego wyrażał się w zakładaniu różnego rodzaju stowarzyszeń i organizacji dobroczynnych.

Nowy Sącz przechodził też modernizację. Od 1900 r. trwały prace nad telefonizacja miasta. W 1911 r. elektrownia miejska umożliwiła wprowadzenie elektrycznego oświetlenia. W latach 1904-1912 trwała budowa wodociąów i kanalizacji miejskiej ${ }^{11}$. W ciagu 30 lat (1880-1910) liczba ludności podwoiła się i wynosiła w 1910 r. 25 tys., z czego 65\% stanowili rzymscy katolicy, 32\% ludność wyznania mojżeszowego i po $1,5 \%$ grekokatolicy i przedstawiciele innych wyznan ${ }^{12}$.

\section{„Mieszczanin” - redaktorzy i program}

Oprócz uwarunkowań politycznych, gospodarczych i społecznych, kształtujacych rynek prasowy w Nowym Sączu, istotna dla powodzenia czasopisma rolę odgrywał redaktor i wydawca. „Mieszczanin” miał kolejno dwóch - Józefa Gutowskiego i Zygmunta Mayera. Okresowo jako wydawca pisma figurowała żona Józefa Gutowskiego, Tekla.

Józef Gutowski (1859-1916) początkowo pracował jako nauczyciel w szkołach ludowych ziemi sądeckiej. Stopniowo działalność społeczna i towarzysząca jej wydawnicza zaczęły zajmować coraz więcej miejsca $\mathrm{w}$ jego życiu. Zaangażował się w rodzący się ruch zawodowy nauczycielstwa w Galicji, w 1896 r. założył Galicyjskie Towarzystwo Nauczycieli Ludowych z siedzibą w Nowym Sączu. W latach 1893-1913 wydawał jego organ prasowy „Szkolnictwo Ludowe”, od 1900 r. redagował „Mieszczanina”, a od 1903 r. „Sądeczanina”. Zorganizował Towarzystwo Właścicieli Realności w Nowym Saczu i przez pewien czas stał na jego czele jako prezes. Poglądy polityczne stawiały go w kręgu Stronnictwa Narodowo-Demokratycznego, sympatyzował też ze Stronnictwem Ludowym. Swoje przekonania wyrażał odważnie i jasno, co rodziło sytuacje konfliktowe, które czasem znajdowały swój finał w sądzie ${ }^{13}$.

Zygmunt Mayer (1867-1919) pracował w szkołach ówczesnego powiatu myślenickiego i podobnie jak Józef Gutowski działał w Towarzystwie Nauczycieli Ludowych i współpracował ze „Szkolnictwem

${ }^{11}$ T. Aleksander, Życie społeczne i przemiany kulturalne Nowego Sacza $w$ latach 1870-1990, Kraków 1993, s. 25-39.

${ }^{12}$ I. Weinfeld, Ludność miejska Galicji i jej skład wyznaniowy (1881-1910), Lwów 1912 (Wiadomości Statystyczne o Stosunkach Krajowych, 24/2), s. 32.

${ }^{13}$ H. Dobrowolski, Gutowski Józef, w: PSB, t. 9, Wrocław 1960-1961, s. 184-185. 
Ludowym". Z powodu swoich poglądów i działalności w 1896 r. został zwolniony z posady nauczyciela. Rozpoczą wówczas wędrówkę po miastach galicyjskich, w których osiadał na pewien czas i nawiazywał współpracę $\mathrm{z}$ wydawanymi tam pismami ${ }^{14}$.

Swój program „Mieszczanin” jasno i konkretnie sformułował w pierwszym numerze pisma z 1 X 1894 r.: ,"Mieszczanin“ nie jest gazeta lokalna, obejmująca sprawy tylko jednego miasta, lecz pismem powszechnem, krajowem, omawiającem interesa wszystkich miast i mniejszych miasteczek, które nie maja własnego organu, słowem całego stanu mieszczańskiego, który coraz bardziej idzie w poniewierkę". Oddziaływanie społeczne pisma zakładało doprowadzenie do utworzenia „Związku miast i miasteczek”, który miał wywalczyć „prawa, stanowi mieszczańskiemu należne". Rozumiano przez nie zreformowanie ordynacji wyborczej, aby głosy mieszczańskie nie ginęły wśród chłopskich, zmniejszenie obciażenia podatkowego, przejęcie - przynajmniej częściowe - handlu z rąk żydowskich. Wzór stanowił Związek Stronnictwa Chłopskiego z własnym pismem „Związek Chłopski”. Redakcja liczyła na poparcie innych stanów, zwiazanych z mieszczaństwem interesami lub wywodzacych się $\mathrm{z}$ niego ${ }^{15}$. Tematykę pisma tworzyć miały przede wszystkim kwestie dotyczące mniejszych miast i miasteczek, ale również „całego życia publicznego"16. Zapraszano „ludzi dobrej woli i szlachetnego charakte$\mathrm{ru}^{\prime 17}$ do nadsyłania korespondencji, gwarantując anonimowość, ale podkreślając konieczność opierania się na prawdzie. Zachęcano również do prenumeraty oraz upowszechniania „Mieszczanina”. Po rocznej przerwie $\mathrm{w}$ wydawaniu pisma program redakcji nie uległ zmianie i w numerze z 1 I 1897 r. deklarowano: „będziemy się starali przede wszystkiem budzić to mieszczaństwo z uśpienia [...] i dazżyć do utworzenia w przyszłości stronnictwa mieszczańskiego"18. Przy zmianie wydawcy i redaktora w 1897 r. oświadczenie powtórzono ${ }^{19}$, przy anonsowaniu wznowienia pisma 15 VI 1903 r. i w następnym numerze z 1 I 1904 r. nie było już oficjalnych deklaracji, lecz kontynuacja dotychczasowej linii, w bardziej stanowczym, a niekiedy nawet konfrontacyjnym tonie.

${ }^{14}$ E. Podgórska, Mayer Zygmunt, w: PSB, t. 20, Wrocław 1975, s. 278-279; Kronika, „Mieszczanin” 1897, nr 24, s. 5-6.

15 Stowo od Redakcyi, „Mieszczanin” 1894, nr 1, s. 1-2, cyt. ze s. 1.

${ }^{16}$ Co „Mieszczanin” pisać będzie, „Mieszczanin” 1894, nr 1, s. 2.

17 Tamże, s. 3.

18 Od Redakcyi, „Mieszczanin” 1897, nr 1, s. 1.

${ }^{19}$ Do Szanownych Czytelników!, „Mieszczanin” 1897, nr 19, s. 1-2. 


\section{Zagadnienia ustrojowe dotyczące samorządu gminnego w Galicji}

Celem „Mieszczanina” było kształtowanie postaw obywatelskich, które skłaniałyby do podejmowania konkretnych działań dla dobra gminy i jej mieszkańców. Zamiast narzekać, należało zgłosić problematyczną sprawę do redakcji „Mieszczanina” lub odpowiedniego urzędu czy instytucji ${ }^{20}$.

Aktywność taka wymagała jednak przynajmniej pewnej orientacji w obowiązujacych regulacjach prawnych, przede wszystkim tych zwiazanych $\mathrm{z}$ funkcjonowaniem samorządu gminnego. W tym celu pismo drukowało podstawowe akty prawne, jak tekst ordynacji wyborczej dla gmin z 12 VIII 1866 r. (z uwzględnieniem późniejszych zmian) ${ }^{21}$ czy ustawy krajowej o ustroju miast i znaczniejszych miejscowości Galicji z 3 VII 1896 r. ${ }^{22}$ Podawało również kryteria, którymi należało się kierować przy wyborze burmistrza - kandydat winien być „uczciwy, pracowity, trzeźwy", znać ustawę gminna, cechować się punktualnościa i łagodnością w obejściu dla każdego, a równocześnie stanowczo dbać o równowagę w budżecie gminy i bezpieczeństwo mieszkańców. Radni przed wyborem burmistrza powinni zasięgnąć opinii swoich wyborców, dobrze przemyśleć decyzję i nie ulegać agitacji ${ }^{23}$. „Mieszczanin” podawał też wskazówki dla radnych: powinni oni utrzymywać stały kontakt $\mathrm{z}$ wyborcami, wywiązywać się z obowiązku udziału w posiedzeniach rady, sprawy omawiać publicznie, udostępniać protokoły z obrad rady, dbać o dobrobyt ludności, terminowo uchwalać budżet, unikać nakładania nowych ciężarów podatkowych, a starać się obniżać już obowiązujące, dbać o oświatę. Urzędnicy miejscy swoimi kompetencjami powinni byli służyć mieszkańcom, udzielając im porad w załatwianiu spraw urzędowych ${ }^{24}$.

Większe miasta Galicji, wyodrębnione ustawa gminną z 1889 r., do których należał także Nowy Sącz, podjęły wspólne działania, wychodząc z założenia, że ,wiele złego dolega wszystkiem miastom, a głos wspólny więcej znaczy, aniżeli nawoływanie reprezentacyi pojedynczego

20 Obowiazki obywatelskie, „Mieszczanin” 1894, nr 1, s. 4-5.

${ }_{21}$ Ordynacya wyborcza dla gmin, „Mieszczanin” 1895, nr 2-9.

${ }_{22}^{2}$ Ze spraw krajowych. Nowa ustawa gminna dla 131 gmin, „Mieszczanin” 1897, nr 13, s. 3-4; nr 14, s. 4; Watpliwości z nowej ustawy gminnej z dnia 3 lipca 1896 r. dla 131 gmin, „Mieszczanin” 1897, nr 24, s. 4-5.

${ }^{23}$ Kogo wybierać na burmistrza?, „Mieszczanin” 1894, nr 6, s. 84-86.

${ }_{24}$ Złote stowa (które każdy radny zachować powinien $w$ pamięci), „Mieszczanin” 1905, nr 5, s. 2-3; nr 6, s. 3. 
grodu"25. Organizowały więc wspólne wiece, na których spotykali się ich burmistrzowie, podjęto także próbę wydawania własnego tytułu prasowego - „Samorząd Gminny”. Jednak „Mieszczanin” negatywnie oceniał zarówno jedna, jak i drugą inicjatywę: „Wszelako, ani o wiecach burmistrzów miast większych, ani też o ich organie, absolutnie dodatniego sądu wydać nie można" ${ }^{26}$. Nie znalazły też uznania wspólne zabiegi większych miast mające na celu podejmowanie działań w ich interesie $\mathrm{w}$ związku z nowymi regulacjami prawnymi, np. dotyczące obciążenia finansowego miast na podstawie ustawy drogowej, zniesienia propinacji czy reformy ordynacji wyborczej ${ }^{27}$.

„Mieszczanin” z rozczarowaniem i obawą obserwował kierunek rozwoju autonomii galicyjskiej, w opinii pisma zdecydowanie negatywny. Władzom autonomicznym wszystkich szczebli zarzucał coraz mocniejsze powiązania z władzami rządowymi, a jednym i drugim - opanowanie ich przez szlachtę, bądź osobiście, bądź poprzez wpływy. Z tego powodu posługiwał się określeniem „pańska autonomia”"28 lub „szlachecko-pańska autonomia”29. Redakcja podkreślała, że „nie każda Władza sama z siebie jest dobra" ${ }^{30}$. Władze samorządowe wyższego szczebla (rady powiatowe, Wydział Krajowy) powinny wywiązywać się z obowiązku kontroli organów niższego szczebla, tymczasem stały się one synekurami i kółkami towarzyskimi. O funkcjonowaniu władz gminnych pisano: „Bezrząd, nieuczciwość, nieład w administracyi, łapczywość na grosz i dobro publiczne - a zanik poczucia moralności publicznej, święca dziś prawdziwe orgie!"31, tych zaś, w których rękach władza gminna spoczywała, określano mianem „hien magistrackich”. Część z urzędów gminnych zasłużyła według „Mieszczanina” na miano „siedliska różnego rodzaju nadużyć", a niektórzy burmistrzowie i prezydenci miast wykazywali „brak rozumu, powagi w wystapieniach i etyki w działaniu” ${ }^{2}$. Z kolei

${ }^{25}$ Ostatni wiec burmistrzów miast większych, „Mieszczanin” 1895, nr 11, s. 163.

26 Tamże.

27 Wiec burmistrzów, „Mieszczanin” 1897, nr 5, s. 4; Na psy schodzq nasi ojczymowie, „Mieszczanin” 1904, nr 13, s. 2; Nowa reforma wyborcza, „Mieszczanin” 1906, nr 6, s. 3-4.

${ }^{28}$ Pańska autonomia, „Mieszczanin” 1897, nr 13, s. 1-2.

${ }^{29}$ Dlaczego nasz kraj biedny?, „Mieszczanin” 1907, nr 19, s. 1-2.

30 Niewidzialna władza wykonawcza, „Mieszczanin” 1897, nr 8, s. 1.

${ }^{31}$ Hyeny magistrackie, „Mieszczanin” 1904, nr 6, s. 1-2.

32 Nasi ojczymowie, „Mieszczanin” 1904, nr 8, s. 1. Na temat konfliktów w łonie rady miejskiej i magistratu zob. np. S. Rejman, Różnice w interpretacji prawodawstwa gminnego na przykładzie kryzysu zwiazanego z obsadzeniem stanowiska burmistrza Rzeszowa (maj 1891 - luty 1893), w: Dzieje biurokracji na ziemiach polskich, t. 2, red. A. Górak, D. Magier, Lublin-Siedlce 2009, s. 183-202; taż, Ludwik Klemens Topolski- 
starostów nazywano „kacykami powiatowymi” i zarzucano im, że w podległych im urzędach zalegaja niezałatwione sprawy ${ }^{33}$. Protestowano przeciwko korupcji i łączeniu wysokich stanowisk ${ }^{34}$.

Wina za ten stan rzeczy pismo obarczało po części radnych, określając ich jako „gromadę ludzi, pędzonych jak stado baranów, na rzeź, pokorne, bezwładne i bezsilne, ulegajace przewrotnemu burmistrzowi, lub pierwszemu lepszemu drabowi z »bacczkiem« u czapki - lub bez bączka!”35. „Mieszczanin” podkreślał, że bycie radnym to odpowiedzialne i godne zajęcie, sami zaś radni powinni mieć odpowiednie kwalifikacje do niego: być w sile wieku (30-55 lat), wykazywać bystrość umysłu, niezależność poglądów, nie ulegać chciwości, reprezentować wyborców. Rzeczywistość była zgoła odmienna, pismo z przykrościa stwierdzało: „W Galicyi każdy poseł, a jeszcze bardziej radny myśli, że z chwila uzyskania mandatu, otrzymał równocześnie nieomylność we wszystkich sprawach oraz nieograniczoną wolność w działaniu"36. Wymagania stawiano też urzędnikom miejskim, wychodząc z założenia, że jeśli ktoś pobiera wynagrodzenie za wykonywanie swego urzędu, powinien mieć wyznaczone godziny pracy i zakres odpowiedzialności, co należy podać do wiadomości publicznej i kontrolować. Zarzuty te odnosiły się przede wszystkim do wyższych urzędników, niżsi bowiem, niepewni stałości swojej posady, których Ireneusz Ihnatowicz określił mianem „biedoty urzędniczej”, na lekceważące traktowanie swoich obowiązków nie mogli sobie pozwolić ${ }^{37}$.

sekretarz rzeszowskiego magistratu $i$ Rady miejskiej $w$ latach 1885-1903, „Prace Historyczno-Archiwalne" 22, 2010, s. 35-47.

${ }^{33}$ Kacyki powiatowe, „Mieszczanin” 1904, nr 5, s. 2.

${ }_{34}$ Bezprawia autonomiczne, „Mieszczanin” 1904, nr 5, s. 1-2; W krzyżowym ogniu, „Mieszczanin” 1904, nr 7, s. 2.

${ }^{35}$ Co zdziałać może „prawdziwa” Rada gminna ?, „Mieszczanin” 1904, nr 10, s. 1-2.

${ }_{36}$ Złote słowa, „Mieszczanin” 1907, nr 21, s. 1; O zadaniach naszych radnych i posłów wobec społeczeństwa, „Mieszczanin” 1907, nr 23, s. 1 (cyt.).

${ }^{37}$ Kołowacizna $w$ gospodarce miejskiej, „Mieszczanin” 1904, nr 4, s. 1-2; Nasi ojczymowie, „Mieszczanin” 1904, nr 8, s. 1; Stuszne narzekania (Głos z kraju), „Mieszczanin” 1904, nr 12, s. 1-2; Najpilniejsze żqdania (Apel do sejmu $i$ Wydziału krajowego), „Mieszczanin” 1908, nr 19, s. 4-5; I. Ihnatowicz, Urzędnicy galicyjscy..., s. 214. Pomimo krytycznych ocen autonomia galicyjska przyczyniła się do wykształcenia się aparatu administracyjnego, a urzędnicy w nim pracujący po odzyskaniu przez Polskę niepodległości mogli przejąć sprawy państwowe i samorządowe w swoje ręce; zob. S. Rejman, Samorzad miejski w okresie autonomii galicyjskiej i II RP-ciagłość i zmiana, w: Kulturotwórcza rola samorzadów terytorialnych. Historia-wspótczesność - perspektywy, red. Z. Lenart, M. Menz, Warszawa 2018, s. 55-77. 


\section{Kwestie gospodarcze}

\section{Podatki}

Obowiązek płacenia podatków na rzecz państwa przeważnie nie budził entuzjazmu wśród obywateli. Ich niechęć wzrastała, jeśli sam system podatkowy postrzegany był jako niesprawiedliwy i niejasny, a tak właśnie było w Galicji. W połączeniu z trudną sytuacją gospodarcza w prasie często padały stwierdzenia w rodzaju: „Mieszczanin po mniejszych miastach i miasteczkach jęczy pod ciężarem nadzwyczaj wysokich podatków" ${ }^{38}$. Podstawą dochodów państwa były podatki, funkcjonujące jeszcze w pierwszej połowie XIX w., stopniowo i nieznacznie uzupełniane nowymi. Główne wpływy przynosiły podatki pośrednie, tj. podatki konsumpcyjne, cła i dochody z monopoli: solnego i tytoniowego. W miarę upływu czasu rósł udział podatków bezpośrednich trzech sprzed 1848 r., tj. gruntowego (opartego na katastrze józefińskim i szacunkowo ustalanym dochodzie z parceli), od budynków (na podstawie czynszów najmu), zarobkowego (z podziałem ludności na cztery grupy, z których każda płaciła z góry oznaczone sztywne stawki podatkowe) oraz wprowadzonego w $1849 \mathrm{r}$. podatku dochodowego. Ten ostatni dzielił podatników na trzy klasy: dotychczasowi płatnicy podatku zarobkowego, utrzymujący się z pracy najemnej, uzyskujący dochody z odsetek od kapitałów i rent. Wysokość podatku uzależniona była od zeznania (fasji) podatnika, ale w praktyce władze podatkowe często fasje korygowały. U schyłku XIX w. zróżnicowanie podatku zarobkowego oparto na nowych zasadach (podział na przedsiębiorstwa wielkokapitalistyczne, zupełnie małe i wszelkie pozostałe) oraz wprowadzono podatek osobisto-dochodowy. Miały go płacić osoby fizyczne od wszelkich dochodów stałych i zmiennych przekraczających kwotę 600 zł reńskich rocznie. Podstawę ustalenia podatku podawał płacacy go, a jego wymiar ustalały komisje, w połowie wybierane przez podatników, w połowie mianowane ${ }^{39}$. „Mieszczanin” zachęcał do zgłaszania zmian w użytkowaniu ziemi do katastru (np. zamiana pola na łąkę, łąki na nieużytek), ponieważ wpływało to na wysokość podatku. W 1895 r. poseł do Rady Państwa ksiądz Leon Pastor przedstawił na łamach pisma zasady rewizji podatku gruntowego w sposób zrozumiały dla przeciętnego obywatela - geometrzy ewidencyjni mieli objeżdżać gminy, przyjmować zażalenia w sprawie

38 Obecna kadencya Sejmu krajowego, „Mieszczanin” 1895, nr 1, s. 1.

${ }^{39}$ Historia państwa i prawa Polski, red. J. Bardach, t. 4: K. Grzybowski, Od uwtaszczenia do odrodzenia państwa, uzup. i przyg. do dr. J. Bardach, S. Grodziski, M. Senkowska-Gluck, Warszawa 1982, s. 406-409. 
niewłaściwego zaklasyfikowania gruntów i sprawdzać ich zasadność. Autor zachęcał do korygowania klasyfikacji, a zarazem przestrzegał, aby nie składać wniosków bez przyczyny ${ }^{40}$.

Zmiany w systemie podatkowym z 1896 r. „Mieszczanin” powitał z nadzieja, która jednak okazała się bezpodstawna. W 1904 r. wyrażał przekonanie, że właściciele wielkich posiadłości ciężar podatków przerzucili na miasta (podatek gruntowy był niższy od czynszowego), a powszechne oburzenie budziło samowolne podwyższanie podatków przez inspektorów podatkowych, którzy na własną rękę poszukiwali informacji, nie zawsze udokumentowanych, o dochodach podatników. Rozgoryczenie powodował też fakt, że osoby, które w dobrej wierze wypełniły fasje (o czym pismo regularnie przypominało), zostały bez dowodów uznane za oszustów podatkowych. Mimo wnoszenia odwołań (rekursów) w sprawie wysokości nałożonego podatku, władze przystępowały do jego ściagania, nie czekając na wynik postępowania odwoławczego. Podatnicy musieli więc bronić się sami. Pismo nawoływało do zawiazywania „Towarzystw prawnej obrony podatników” na wzór działających w Krakowie i Lwowie, które udzielały tanich porad prawnych i zabiegały o wniesienie kwestii podatkowych na forum Sejmu ${ }^{41}$.

\section{Handel artykułami żywnościowymi}

Prawie tak istotna jak podatki była dla mieszkańców miast kwestia zaopatrzenia w artykuły żywnościowe. Okazję dawały cotygodniowe targi i odbywające się kilka razy w roku jarmarki. Ustawa gminna krajowa z 1866 r. stanowiła, że sprawy związane z organizacją handlu na terenie gminy należą do zakresu własnego działania gminy, jej więc obowiązkiem było ustalenie prawnych i organizacyjnych uwarunkowań wymiany handlowej. Składało się na nie uchwalanie przez rady gminne regulaminów targowych i taryf opłat, przygotowanie placów i ulic, na których odbywał się handel oraz ich uprzątanie, troska o bezpieczeństwo. W miarę upływu czasu podejmowano też działania mające na celu

${ }^{40}$ Rewizya katastru, „Mieszczanin” 1894, nr 4, s. 53-54; ks. L. Pastor, Rewizya podatku gruntowego, „Mieszczanin” 1895, nr 16, s. 243-244.

${ }^{41}$ Co nam przynosi rzeczywiście reforma podatkowa ?, „Mieszczanin” 1897, nr 16, s. 1-2; Wobec ucisku... podatkowego, „Mieszczanin” 1904, nr 1, s. 1-2; Mydlenie oczu, „Mieszczanin” 1904, nr 3, s. 3-4; Galicyjskie nadużycia podatkowe przed parlamentem, „Mieszczanin” 1904, nr 9, s. 1-2; Krzywda wotajqca o pomste..., „Mieszczanin” 1905, nr 3, s. 1; Bezprawie podatkowe, „Mieszczanin” 1905, nr 11, s. 3-4; Moralność podatkowa, „Mieszczanin” 1905, nr 14, s. 2-3; Towarzystwo prawnej obrony podatników w Krakowie, „Mieszczanin” 1908, nr 1, s. 4. 
modernizację infrastruktury targowej (nowe rzeźnie miejskie, targowice zwierzęce na obrzeżach miasta, zadaszanie kramów, hale targowe). Ich skala była związana $\mathrm{z}$ finansami gminy, władzom państwowym zależało przede wszystkim na stworzeniu odpowiednich warunków badania weterynaryjnego i uboju zwierząt. Mieszkańcy miast natomiast najbardziej zainteresowani byli możliwością zakupu towarów bezpośrednio od producentów żywności. Utrudniał to proceder wykupywania artykułów żywnościowych przez hurtowników i kupców, którzy następnie sami je sprzedawali, dodając do ceny producenta swoją marżę. Regulaminy targowe ustanawiały godziny, w których nie można było dokonywać zakupów hurtowych, a jedynie detaliczne. Hurtownicy często ubiegali ludność miasta, wychodząc poza jego granice i wykupując towary na drogach do niego prowadzacych. Zakazywano takich praktyk, ale policja miejska nie mogła działać poza obszarem miasta ${ }^{42}$. „Mieszczanin” ubolewał, że traca na tym i miasta, nie pobierając opłaty targowej, i ich mieszkańcy, kupując po zawyżonych cenach ${ }^{43}$.

\section{Wspieranie rozwoju przemysłu krajowego}

„Mieszczanin” był goracym orędownikiem rozwoju gospodarczego Galicji dzięki wykorzystaniu rodzimych sił i zasobów ${ }^{44}$. W wielu publikowanych na jego łamach artykułach analizowano sytuację ekonomiczna i wskazywano pożądane kierunki rozwoju. Podkreślano pożytki płynące z łączenia środków finansowych, które mogłyby być wykorzystane do budowy kolei lub zakładania przedsiębiorstw, jak młyny, browary, fabryki. Rzemieślnicy, rolnicy, kupcy mogliby tworzyć spółki i nabywać potrzebne narzędzia do pracy oraz materiały hurtowo z fabryki po

${ }^{42}$ Więcej nt. organizacji handlu przez gminy zob. S. Rejman, Działalność samorzqdów gminnych $w$ zakresie bezpieczeństwa i porzadku publicznego $w$ znaczniejszych miastach zachodniogalicyjskich w latach 1889-1914, Rzeszów 2013, s. 189-234.

${ }^{43}$ Czy jest ustawa targowa?, „Mieszczanin” 1894, nr 2, s. 17-18; Dlaczego my zawsze ostatni?, „Mieszczanin” 1895, nr 2, s. 19-20.

${ }^{44}$ Więcej nt. życia gospodarczego Galicji zob. K. Broński, Rozwój gospodarczy większych miast galicyjskich w okresie autonomii, Kraków 2003; P. Franaszek, Kluczowe zagadnienia dziejów gospodarczych Galicji, w: Galicja. Studia z dziejów społeczno-gospodarczych, red. M. Baczkowski, T. Kargol, Kraków 2017, s. 67-82; P. Miodunka, Demograficzny i gospodarczy potencjat matych miast południowej Polski od końca XVI do poczatku XIX wieku, RDSG, t. 78, 2017, s. 131-161; M. Śliwa, Nędza galicyjska. Mit i rzeczywistość, w: Galicja i jej dziedzictwo, t. 1: Historia i polityka, red. W. Bonusiak, J. Buszko, Rzeszów 1994, s. 145-155; zob. też K. Broński, Miasta galicyjskie we wspótczesnej historiografii. Przeglad badań i problemów, w: Pamięć, wybór, tożsamość. Szkice o mieście, red. K. Broński, R. Kusek, J. Sanetra-Szeliga, Kraków 2016, s. 25-47. 
niższych cenach. Zbyt znalazłyby przedmioty codziennego użytku lub luksusowe, ręcznie wykonane. Ale praktyka pokazywała, że trudno było walczyć z przekonaniem o lepszej technologii produkcyjnej i wyższych kwalifikacjach fachowców z krajów bardziej uprzemysłowionych. Jako przykład pismo podawało cukrownię w Przeworsku, która miała ruszyć jesienia $1895 \mathrm{r}$. Wiązane $\mathrm{z}$ nia duże nadzieje na zarobek polskich rzemieślników okazały się płonne - budowę i urządzenie zakładu oddano przedsiębiorcom niemieckim i czeskim (wyjątkiem była tylko fabryka H. Cegielskiego, która dostarczyła kotłów); fachowców, materiały i zatrudniony personel sprowadzono z zagranicy ${ }^{45}$.

Do poprawy krajowego przemysłu miały się przyczynić uzupełniające szkoły przemysłowe ${ }^{46}$. Tymczasem według pisma „nasze krajowe warsztaty przemysłowe nie odpowiadają rzeczywistej potrzebie, w przeważnej ilości wypadków prosperuja licho i wcale nie cieszą się sympatya tych warstw społecznych, dla których urządzone zostały" ${ }^{47}$. Uczniów było mało, nauczycieli dużo, nauka nie dawała praktycznych umiejętności z powodu przerostu teorii nad praktyka, wyroby szkolne stanowiły konkurencję dla miejscowych rzemieślników, chociaż wcale nie były dobrej jakości, jedynie te prezentowane na wystawach wykonane były należycie, chociaż często przez nauczycieli, a nie uczniów ${ }^{48}$.

Z uznaniem i satysfakcja „Mieszczanin” informował natomiast o powstawaniu i działalności stowarzyszeń, których celem było wspieranie rozwoju gospodarczego, jak np. Towarzystwo Zachęty Popierania Przemysłu Krajowego, przygotowujacych wystawy przemysłowe popularyzujące osiagnięcia i nowe rozwiązania technologiczne, czy Krajowe Towarzystwo Parcelacyjne, propagujące parcelację obszarów dworskich w taki sposób, aby zapobiegać rozdrabnianiu ziemi i pośredniczyć między właścicielami większych posiadłości zmuszonymi do sprzedaży a włościanami, którzy chcieli kupić ziemię, ale niezbyt drogo. Z kolei

45 Jak powinniśmy sobie pomagać, „Mieszczanin” 1894, nr 2, s. 22-24; Nasz przemyst domowy i jego przyszłość, „Mieszczanin” 1897, nr 5, s. 2; Cukrownia w Przeworsku, „Mieszczanin” 1895, nr 18, s. 278.

${ }^{46}$ Uzupełniajace szkoły przemysłowe funkcjonowały w ramach systemu szkolnictwa zawodowego, na który składały się: państwowe szkoły przemysłowe, krajowe szkoły przemysłowe, uzupełniające szkoły przemysłowe, szkoły rolnicze, szkoły kupieckie, szkoły muzyki i śpiewu. Ponadto do zawodu przygotowywały też kursy przemysłowe i rolnicze; zob. J. Draus, R. Terlecki, Historia wychowania, t. 2: Wiek XIX i XX, Kraków 2005, s. 101.

${ }^{47}$ Nasze krajowe szkoty przemystowe, „Mieszczanin” 1895, nr 22, s. 338-341.

${ }^{48}$ Los uzupetniajacych szkót przemystowych, „Mieszczanin” 1895, nr 10, s. 152-153; Czy nędzy rzemieślników zapobiegna obecne szkoty przemysłowe?, „Mieszczanin” 1897, nr 1, s. 1-2; Los uzupetniajacych szkót przemysłowych, „Mieszczanin” 1897, nr 21, s. 6. 
Krajowe Towarzystwo dla Wytworzenia Przemysłu Fabrycznego w Krakowie zakładało wiele stowarzyszeń i zakładów, w których członkostwo zarezerwowane było tylko dla chrześcijan ${ }^{49}$.

\section{Żydzi w życiu gospodarczym Galicji}

Ludność żydowska miała duży udział w populacji i gospodarce Galicji, która Tomasz Gąsowski określił jako „żydowski matecznik” ${ }^{0}$. „Nawet niechętni Żydom robili zakupy w najbliższym sklepiku żydowskim, szyli ubrania u żydowskiego krawca, zelowali buty u żydowskiego szewca, naprawiali zegarki u żydowskiego zegarmistrza. Żaden dwór nie mógł się obejść bez swego faktora Szmula czy Moszka, zaufanego dostawcy, dzierżawcy i informatora. A w dużych miastach trudno było ominąc żydowskiego lekarza, adwokata, księgarza czy antykwariusza" ${ }^{51}$. Starania polskich rzemieślników, próbujących swoimi wyrobami konkurować z importowanymi, uważanymi powszechnie za tańsze, lecz gorszej jakości, oraz polskich kupców zakładajacych małe sklepy i budujacych swoją pozycję poprzez mały zysk, szybki obrót i uprzejma obsługę często miały niewielkie szanse powodzenia. Przeszkodą była duża solidarność przedsiębiorców żydowskich, a mała polskich oraz wrodzone zdolności do handlu przypisywane Żydom. „Mieszczanin” podawał przykłady sytuacji, w których powodzenie założonego polskiego sklepu powodowało, że powstawały następne, chociaż na rynku nie było dla nich miejsca, co powodowało, że stanowiły wobec siebie konkurencję i w konsekwencji upadały.

Stawanie po stronie kupców i wytwórców polskich nie zawsze przybierało szlachetne formy. Czasopismo pochwalało przeciwstawianie się mieszkańców osiedlaniu się w ich miasteczkach Żydów, chociaż prowadziło to często do niehumanitarnych postaw czy rękoczynów. Tak było np. w Żywcu, w którym zwyczajowo Żydzi mieszkali poza granicami miasta, we wsi Zabłocie. Próby wyłamania się z tej tradycji przez nowo przybyłych urzędników czy przedsiębiorców pochodzenia żydowskiego

${ }^{49}$ Dwa nowe Towarzystwa, „Mieszczanin” 1895, nr 7, s. 107-108; Z Towarzystwa zachęty przemystu krajowego, „Mieszczanin” 1895, nr 11, s. 166; Popierajmy przemyst krajowy! Kupujmy u swoich!, „Mieszczanin” 1897, nr 1, s. 2-3; Ruchome wystawy, „Mieszczanin” 1904, nr 9, s. 3.

50 T. Gąsowski, Galicja - „żydowski matecznik”, w: Galicja i jej dziedzictwo..., t. 2, s. 125-134. Według spisu państwowego ludność wyznania izraelickiego w $1910 \mathrm{r}$. stanowiła ok. 30\% w Galicji Zachodniej i 42\% w Galicji Wschodniej; zob. I. Weinfeld, dz. cyt., s. 44,52 .

${ }^{51}$ T. Gasowski, dz. cyt., s. 128. 
budziły czynny opór mieszkańców. Występki traktowane jako obraza religii katolickiej popełnione przez przedstawicieli społeczności żydowskiej były surowo potępiane, przy czym przeważnie przypisywano im intencjonalność działania. Oburzenie budziły też jakiekolwiek przykłady uprzywilejowania Żydów, np. związane z rozwijającym się w Galicji chasydyzmem i działalnościa cadyków ${ }^{52}$, czy próby wkraczania Żydów w sfery życia zarezerwowane dla ludności katolickiej (jak członkostwo w komitetach kaplic rzymskokatolickich) ${ }^{53}$.

\section{Ustawa o wypoczynku niedzielnym}

Dużo emocji na łamach „Mieszczanina” budziła ustawa o wypoczynku niedzielnym, nie tylko z powodów socjalnych. Prawo pracy rozwijało się w cesarstwie austriackim powoli i chociaż formalnie przyjmowało zasadę wolności umowy i równości stron, w praktyce nie tylko przetrwały różnice prawne sytuacji pracodawcy i robotnika, ale nawet pojawiały się nowe. Osoba bez źródła utrzymania (majątku czy pracy) traktowana była jak włóczęga, a zatem sytuacja zmuszała ją do zawarcia umowy. Wobec pracodawcy robotnicy nie mogli wystapić jako zorganizowana siła, ponieważ traktowano to jako „zmowę” zawartą dla uzyskania lepszych warunków pracy, co było przestępstwem. Początek okresu konstytucyjnego przyniósł pogorszenie sytuacji robotników w zakresie wypoczynku niedzielnego, ponieważ ustawa z $25 \mathrm{~V} 1868$ r. uchyliła przepisy ograniczające pracę w święta. Powoływała się przy tym na konstytucję i zapis o prawach obywateli stwierdzający, że nikogo nie można zmusić do udziału w czynnościach religijnych.

Obowiazkowy wypoczynek niedzielny wprowadzano stopniowo w latach 1884-1895. Prawo przewidywało, że zakłady pracy powinny być w niedzielę nieczynne albo też ich czas pracy ograniczony. Istniały jednak liczne wyjątki stałe lub doraźne ${ }^{54}$. „Mieszczanin” podkreślał znaczenie społeczne i religijne niedzielnego wypoczynku, ale dostrzegał też konflikt interesów w tym, że święta społeczności katolickiej i żydowskiej wypadają w inne dni tygodnia. Żydzi, świętujący w sobotę, mogli pracować $\mathrm{w}$ niedzielę, co prawda nie publicznie i bez hałasu. Było to także dozwolone przedstawicielom niektórych zawodów, jak piekarze,

${ }^{52}$ Więcej na ten temat zob. np. T. Jelonek, Chasydzi: radośni mistycy żydowscy, Kraków 2007.

${ }^{53} Z$ izby sadowej (Obraza religii katolickiej), „Mieszczanin” 1894, nr 3, s. 39-41; Na kresach II Żywiec, „Mieszczanin” 1895, nr 10, s. 146-147; Przywilej hierarchów synagogi żydowskiej (Korespondencya z Kraju), „Mieszczanin” 1895, nr 12, s. 182-183.

${ }^{54}$ Historia państwa i prawa Polski..., t. 4, s. 394-406. 
cukiernicy, rzeźnicy, kwiaciarze. Pismo podziwiało dyscyplinę Żydów, którzy szanowali swoje święta, zdawało się, że bez uszczerbku dla zysków. Nawoływało, aby katolicy także święcili swoje i nie prowadzili wówczas interesów z Żydami ${ }^{55}$.

\section{Troska o lasy}

Redakcja monitorowała regulacje prawne dotyczące różnych dziedzin życia gospodarczego, kształtując przy okazji pożądane według niej postawy obywateli. Wiele miejsca poświęcano na łamach pisma potrzebie zadbania o lasy (przede wszystkim w górach), które po części zostały wycięte, aby pozyskać tereny na pastwiska dla owiec. Nie zdawano sobie wówczas sprawy z konsekwencji, które okazały się katastrofalne - lasy przestały odgrywać rolę czynnika stabilizującego stosunki wodne i chroniącego zbocza górskie przed erozja, pastwiska zamieniały się w ugory. $\mathrm{W}$ artykułach podkreślano znaczenie lasów i nawoływano do ponownego zalesiania, wskazując, że przykład powinni dawać właściciele większych majątków. Propagowano hasło: „Szanujcie lasy! Sadźcie lasy!”56. Kwestię tę wiązano z zabiegami o regulację rzek w Galicji - wobec zapowiedzi realizacji tego projektu „Mieszczanin” ostrzegał przed lekceważeniem górskich rzek i potoków, na których budowano zbyt słabe umocnienia, niszczone następnie przez wezbrane wody. Regulację górskich rzek należało łączyć z zalesianiem stoków ${ }^{57}$. Pismo podkreślało również, że właściciele gruntów, którzy z tytułu ich posiadania płacili podatek, powinni mieć udział w zyskach $\mathrm{z}$ myślistwa, jeśli polowania odbywały się na ich ziemi, a gmina pobierała $z$ tego tytułu czynsz dzierżawny. Dzierżawę należało powierzać dobremu myśliwemu, który zadba o zwierzynę, a nie komukolwiek za symboliczną kwotę, kto jedynie będzie korzystał z łowieckich możliwości, nie dbając o stan zwierzyny i nie odnawiając go. „Mieszczanin” stanowczo opowiadał się przeciw kłusownictwu ${ }^{58}$. Zatem $\mathrm{w}$ zakresie korzystania ze środowiska przyrodniczego pismo prezentowało postępowe również dziś poglądy, opowiadając się

${ }_{55}$ Ustawa o spoczynku $w$ niedzielę $i w$ dni świateczne, „Mieszczanin” 1895, nr 9, s. 137-138; Nowa ustawa o święceniu niedziel i świat uroczystych, „Mieszczanin” 1895, $\mathrm{nr}$ 10, s. 144; Prawo pensyjne i odpoczynek niedzielny dla urzędników prywatnych, „Mieszczanin” 1895, nr 13, s. 198-199; Odpoczynek niedzielny w publicznych urzędach, „Mieszczanin” 1897, nr 1, s. 4.

${ }^{56}$ Las i jego wptywy, „Mieszczanin” 1895, nr 2-5 (cyt. za: nr 5, s. 69-70); Las i jego znaczenie, „Mieszczanin” 1895, nr 19, s. 292-293.

${ }_{57}$ O regulacyi rzek $w$ Galicji, „Mieszczanin” 1895, nr 3, s. 33.

${ }^{58}$ Myśliwstwo $w$ mniejszych miastach $i$ miasteczkach, „Mieszczanin” 1894, nr 5, s. $70-71$. 
za poszanowaniem praw natury, rozsądnym, a nie rabunkowym korzystaniem z jej zasobów, liczeniem się z siłami jej żywiołów i docenianiem walorów obcowania z nią.

\section{Regulacje prawne}

\section{Prawo swojszczyzny i jego nowelizacje}

Ważnym prawem z zakresu swobód obywatelskich była możliwość swobodnego wyboru miejsca pobytu przez obywateli państwa. Tymczasem cesarstwo austriackie, a później monarchia austro-węgierska stawiały w tej mierze wyraźne ograniczenia na podstawie ustawy o prawie swojszczyzny z 3 XII 1863 r., znowelizowanej dopiero 5 XII 1896 r., co „Mieszczanin” komentował zreszta krytycznie. Ustawa z 1863 r. stanowiła, że każdy obywatel państwa musi przynależeć do jakiejś gminy, dziedziczac to po ojcu (ewentualnie matce w przypadku dziecka nieślubnego), niezależnie od miejsca stałego pobytu. Konsekwencją przynależności do gminy było prawo do swobodnego w niej pobytu oraz wsparcia ze strony gminy w razie zubożenia. Mimo że konstytucja z 21 XII 1867 r. wprowadziła zasadę wolności przesiedlania się, nadal istniała możliwość przymusowego wysiedlenia i przewiezienia pod eskortą (szupas) nieprzynależnego do gminy do tej gminy, którą wskazywało jego prawo swojszczyzny. Powodów wysiedlenia mogło być wiele i różnych: przede wszystkim unikanie pracy, brak dochodu lub zarobku, nieobyczajne postępki, korzystanie z dobroczynności publicznej, stwarzanie zagrożenia dla bezpieczeństwa osób i mienia, w późniejszym czasie także działania mogące zaburzyć ustalony ład społeczny i wskazujące na związki z ideami socjalistycznymi. Oprócz dziedziczenia prawo przynależności do gminy można było otrzymać na mocy decyzji gminy. Nowelizacja z 1896 r. otwierała drogę do wystapienia z takim wnioskiem osobom, które przebywały w gminie przynajmniej 10 lat bez przerwy i nie korzystały w tym czasie z publicznej dobroczynności ${ }^{59}$. „Mieszczanin” podkreślał, że każdy obywatel powinien mieć swobodę wyboru miejsca osiedlenia się, a także prawo do opieki państwa w razie choroby. Wskazywał, że stosunki kapitalistyczne wymuszają na robotnikach wędrówkę w poszukiwaniu pracy. W razie choroby sa oni odstawiani do miejscowości, w której nie mieszkali, nikogo nie znają i nikt ich nie zna, moga więc być wzięci za osoby tylko korzystające $\mathrm{z}$ dobroczynności. Takie

${ }^{59}$ Historia państwa i prawa Polski..., t. 4, s. 307-308, 356-357. 
rozwiązanie nie jest też opłacalne dla gmin, szczególnie tych biedniejszych, które nie korzystaja z pracy zdrowych osób, a chorym muszą udzielić wsparcia ${ }^{60}$.

\section{Wprowadzenie w sądownictwie law przysięgłych}

Duży wpływ na życie obywateli miała oczywiście organizacja wymiaru sprawiedliwości. W cesarstwie austriackim podstawy nowego ustroju sądów stworzyły akty prawne z lat 1850-1854, w którym najniższą instancją były urzędy powiatowe, działające jako sądy. Ponad nimi stały trybunały I i II instancji, a instytucją odwoławczą był Najwyższy Trybunał Sprawiedliwości. Zmiany wprowadziła ustawa zasadnicza z 21 XII $1867 \mathrm{r}$. Zakładała ona oddzielenie we wszystkich instancjach wymiaru sprawiedliwości od administracji, rozprawy sądowe ustne i jawne, wydawanie wyroków przez sądy w imieniu cesarza przez sędziów przez niego mianowanych, wprowadzenie ławy przysięgłych w sprawach karnych większej wagi, przestępstw politycznych i prasowych. Ten program był realizowany powoli i ostatecznie nie został $\mathrm{w}$ pełni wdrożony. Wprowadzono jednak przysięgłych do spraw prasowych (ustawa z 9 III 1869 r.) oraz w przypadku cięższych zbrodni i spraw politycznych (ustawa z $23 \mathrm{~V} 1873 \mathrm{r}$.).

Nową strukturę nadano sądom na mocy regulacji z lat 1895-1896 $6^{61}$, czyli w czasie, kiedy „Mieszczanin” stawiał pierwsze kroki na rynku prasowym i stąd jego żywe zainteresowanie reformą sądownictwa. $\mathrm{Na}$ jego łamach podkreślano potrzebę zmian, za wzór stawiając przykład Bośni i Hercegowiny, gdzie wiele spraw załatwiano ustnie, funkcjonowali ławnicy i obrońca z urzędu dla każdego, a zamiast notariuszy działała bezpłatnie komisja hipoteczna ${ }^{62}$. Duże nadzieje pismo wiązało z instytucją rozjemczych urzędów gminnych, które na mocy ustawy gminnej miały godzić zwaśnione strony. Podkreślano, że procesy sądowe były długie, kosztowne i narzucały werdykt, z którego przynajmniej jedna ze stron, a czasem i obie, nie były zadowolone. Urzędy rozjemcze miały wypracowywać kompromis, nie opierały się na przymusie stawienia się, a osiagnięte porozumienie miało wartość ugody sądowej ${ }^{63}$.

Dopuszczenie przysięgłych do wyrokowania również spotkało się z uznaniem pisma, ponieważ wiązało się z podniesieniem świadomości obywatelskiej ludności. Przysięgłych powoływano spośród mężczyzn mających prawo przynależności do jednej z gmin w Austrii, którzy mieli

\footnotetext{
${ }^{60}$ Pozory łudza, „Mieszczanin” 1897, nr 2, s. 3-4.

${ }^{61}$ Historia państwa i prawa Polski..., t. 4, s. 429-435.

${ }^{62}$ Reforma sqdownictwa, „Mieszczanin” 1894, nr 1, s. 5-8.

${ }^{63}$ Rozjemcze urzędy gminne, „Mieszczanin” 1894, nr 2, s. 18-20.
} 
minimum 30 lat i płacili co najmniej 20 koron (w dużych miastach 40) podatków bezpośrednich. Nie mogły pełnić tej funkcji osoby sądownie karane lub przeciw którym toczyło się postępowanie, urzędnicy, wojskowi, nauczyciele szkół ludowych, pracownicy poczt, kolei, żeglugi parowej. Wymagania te uniemożliwiały zatem dostęp do ław przysięgłych warstwom nieposiadającym i znacznej części warstw średnich z miast. W sporządzaniu listy przysięgłych dużą rolę odgrywał sąd i władze administracyjne, dopiero $\mathrm{z}$ ostatecznej zaakceptowanej listy losowo wyłaniano przysięgłych na jedną kadencję ${ }^{64}$.

„Mieszczanin” w 1905 r. ubolewał, że ławy przysięgłych nie zdały egzaminu - ich członkowie rekrutowali się głównie z ludności wiejskiej, która łatwo było manipulować, a nawet przekupić. Brak wykształcenia często nie dawał się zrównoważyć rozsądkiem i życiowym doświadczeniem. Nie bez znaczenia był też fakt, że zajęcie nie było wynagradzane - pismo proponowało ustanowienie diet ${ }^{65}$. Zarówno więc gminne urzędy rozjemcze, jak i ławy przysięgłych według „Mieszczanina” nie sprawdziły się w praktyce, chociaż samą ideę ich wprowadzenia pismo popierało.

\section{Życie społeczne}

\section{Historia stanu mieszczańskiego w Polsce}

Kształtowanie tożsamości mieszczaństwa redakcja pisma zaczęła od przypomnienia historii tego stanu w Polsce w wielu artykułach i opowiadaniach literackich. W cyklu „Czem byli mieszczanie w Polsce” przedstawione zostały dzieje mieszczaństwa od początków państwowości polskiej do upadku I Rzeczypospolitej. Podkreślono znaczenie prawa o miastach z 1791 r., uchwalonego przez Sejm Wielki (ustawa stała się później częścią Konstytucji 3 maja). Pismo wyrażało przekonanie, że te regulacje prawne potrzebne były już wiek wcześniej, aby mógł się wykształcić mocny stan mieszczański, konkludowano: „upadek mieszczaństwa był zarazem i upadkiem Polski”66. Końcowe lata istnienia I Rzeczypospolitej postrzegane były przez pismo jako czas przebudzenia mieszczan, czego wyrazem był ich udział w insurekcji kościuszkowskiej, symbolizowany przez warszawskiego szewca Jana Kilińskiego.

${ }^{64}$ Historia państwa i prawa Polski..., t. 4, s. 432-433.

${ }^{65}$ Nic - za darmo...!, „Mieszczanin” 1905, nr 4, s. 1-2; Dlaczego wyroki Trybunatów sqdów przysięgtych nie zawsze sq sprawiedliwe i doktadne?, „Mieszczanin” 1908, nr 6, s. 4-5; nr 7, s. 4-5.

${ }^{66}$ Czem byli mieszczanie w Polsce, „Mieszczanin” 1894, nr 3-6; cyt. za: nr 6, s. 84. 
Faktograficzny artykuł poświęcony powstaniu wyszedł spod pióra Marii Wysłouchowej ${ }^{67}$. W opowiadaniu poświęconym Janowi Kilińskiemu narrację włożono w usta byłego konfederata barskiego, który w czasie insurekcji w Warszawie dostał się pod komendę Kilińskiego i wysoko oceniał jego zdolności przywódcze (,tobie nie szewcem, ale wodzem było się urodzić” ${ }^{68}$. Odpierano też zarzuty stawiane mieszczaństwu przez Feliksa Konecznego, dotyczące braku poczucia własnej tożsamości i godności, małego zainteresowania sprawami państwa, dystansowania się wobec własnego stanu poprzez starania o nobilitację szlachecką czy szukanie zbliżenia do tego stanu przez inteligencję. „Mieszczanin” podkreślał, że to szlachta współtworząca uwarunkowania prawne regulujące położenie stanów uniemożliwiała mieszczaństwu rozwój i działalność w ramach stanu mieszczańskiego ${ }^{69}$.

\section{Niespełnione nadzieje pokładane $\mathrm{w}$ inteligencji}

Pismo z żalem podkreślało, że po wywalczeniu konstytucji i wprowadzeniu autonomii społeczeństwo zobojętniało na sprawy publiczne, dlatego tak dużą wagę przykładało do jego ożywienia, a najbardziej zależało mu na mieszczaństwie. Tymczasem w miastach obserwowano „powszechna apatyę, niedołęstwo i nieporadność. [...]. Nikomu do pracy obywatelskiej wziąć się nie chce. Każdy jest zbyt wygodny"70. Z nadzieją spoglądano na inteligencję: „Wy winniście być czołem stanu mieszczańskiego, wy powinniście być sokiem życiodajnym, który przebiega wszystkie arterye i nerwy całego organizmu społecznego"71.

Niestety, według „Mieszczanina” ta nie spełniała oczekiwań, zapominała o swoich chłopskich i mieszczańskich korzeniach, a ukończywszy studia wyższe, dążyła do zbliżenia się do szlachty, która te aspiracje wykorzystywała dla swoich celów ${ }^{72}$. W rezultacie mieszczaństwo pozostawało osamotnione i bez przewodnictwa, a według pisma nawet lud

67 O Kościuszkowskiem powstaniu z roku 1794, „Mieszczanin” 1894, nr 3-6; 1895, nr $1-6$.

${ }^{68}$ Pierwsze poznanie Kilińskiego. Opowiadanie konfederata, „Mieszczanin” 1894, nr 2, s. 18-21, cyt. ze s. 20.

69 Napaść na mieszczaństwo, „Mieszczanin” 1897, nr 21, s. 1-3; nr 22, s. 1-3.

70 Korespondencye, „Mieszczanin” 1905, nr 11, s. 5.

${ }^{71}$ Nasza „Inteligencya”, „Mieszczanin” 1895, nr 21, s. 324-325.

72 Zdrajcy, „Mieszczanin” 1897, nr 10, s. 1-2; Inteligencya wobec ludu i mieszczan, „Mieszczanin” 1897, nr 20, s. 1. Na kryzys tożsamości, przeżywany przez inteligencję u progu XX w., zwracała uwagę E. Paczoska; zob. taż, Między dylematami inteligenta a rozterkami mieszczucha, w: Mieszczaństwo i mieszczańskość $w$ literaturze polskiej drugiej połowy XIX wieku, red. E. Ihnatowicz, Warszawa 2000, s. 211-226. 
wiejski stał wyżej pod względem „poczucia ludzkiej godności i samodzielności politycznej”73. Dlatego „Mieszczanin” nie ustawał w apelowaniu o utworzenie organizacji mieszczańskiej pod przewodem inteligencji. Te starania nie odniosły skutku: „Niestety mieszczaństwo w Galicyi zamiast łączyć się i skupiać do wspólnej pracy dla własnego dobra i całego narodu, stoi nieporadne, wyczekując cudu albo jakiegoś Mesyasza, który by sprowadził lepsze czasy"74.

\section{Powstawanie stowarzyszeń}

Co prawda pojawiły się pierwsze oznaki przemian w świadomości społecznej i próby stowarzyszania się, ale wobec części z nich „Mieszczanin" nie krył rozczarowania, chociaż początki z radością obwieszczał i popierał. We Lwowie w 1897 r. powstało Stowarzyszenie Wzajemnej Pomocy Mieszkańców Miast, którego celem była pomoc w budowie domów, ułatwianie pozyskiwania pożyczek, porady w handlu nieruchomościami, wspieranie władz w poprawie warunków sanitarnych życia w miastach. Organizowano też towarzystwa właścicieli realności (we Lwowie, Nowym Sączu - w tym mieście w działalność tegoż zaangażowany był Józef Gutowski jako sekretarz i prezes), które miały wspomagać swoich członków w protestach przeciwko uciskowi podatkowemu, a także udzielać porad prawnych. Dyskutowano również nad kwestiami modernizacji infrastruktury miejskiej ${ }^{75}$.

Krytycznie oceniało pismo działalność Towarzystwa Szkoły Ludowej $^{76}$, założonego we Lwowie dla uczczenia setnej rocznicy uchwalenia Konstytucji 3 maja. Chociaż idea podnoszenia poziomu oświaty wśród ludu poprzez budowę szkół, zaopatrywanie uczniów w podręczniki i przybory szkolne, tworzenie i wyposażanie czytelni ludowych, premiowanie nauczycieli ludowych znajdowała poparcie „Mieszczanina”, praktyka pozostawiała wiele do życzenia. Składki mające dać podstawę finansowania działalności napływały w skromnej wysokości, raczej od jednostek, a nie ogółu społeczeństwa, a towarzystwo nie zarządzało dobrze

${ }^{73}$ Obudźcie się...!, „Mieszczanin” 1904, nr 2, s. 1.

${ }^{74}$ Organizujmy się!, „Mieszczanin” 1907, nr 1, s. 1-2.

75 Wzajemna pomoc mieszkańców miast, „Mieszczanin” 1897, nr 6, s. 4; Właściciele realności przeciw burmistrzowi, „Mieszczanin” 1907, nr 13, s. 6-7; Pierwszy wiec wtaścicieli realności w Nowym Saczu, „Mieszczanin” 1907, nr 22, s. 5-6; Z ruchu „Zwiazku właścicieli realności” w Nowym Saczu, „Mieszczanin” 1908, nr 16, 17, s. 5-6.

${ }^{76}$ Więcej na ten temat zob. M. Stępowski, Towarzystwo Szkoty Ludowej. Jak powstało, co zrobiło, do czego daży (1891-1911). W 20-ta rocznice powstania Towarzystwa, Kraków 1911. 
swoimi finansami. Ponadto tego typu instytucje tworzyły płatne urzędy, które pismo wprost określało mianem synekur, postulując jednocześnie pracę w strukturach towarzystw bez wynagrodzenia ${ }^{77}$.

\section{Udział mieszczaństwa w wyborach}

\section{Zabiegi o demokratyzację prawa wyborczego i niezależność wyborów}

Wyrazem wzrostu świadomości obywatelskiej mieszczaństwa miał być jego niezależny udział w wyborach, przekładający się na skuteczność forsowania własnych przedstawicieli. Patent lutowy z 26 II $1861 \mathrm{r}$. dzielił wyborców na sześć grup interesów, z których dwie - Kościół katolicki i świat nauki - wprowadzały swoich przedstawicieli do Sejmu Krajowego jako wirylistów, natomiast w czterech pozostałych wybory odbywały się w kuriach: wielkiej własności ziemskiej, izb przemysłowo-handlowych, miejskiej i wiejskiej. Liczba posłów wybieranych przez poszczególne kurie była nieproporcjonalna do liczby wyborców w nich. Skład społeczny i narodowościowy posłów nie odzwierciedlał struktury ludności. Podział wyborców na kurie obowiązywał też przy wyborach do Rady Państwa, która - również na mocy patentu lutowego - została przekształcona w dwuizbowy parlament z Izbą Panów (członkowie dynastii stawali się jej członkami z urodzenia, pozostali z urzędu lub woli cesarza) i Izbą Poselska.

Starania o demokratyzację prawa wyborczego przyniosły efekty $\mathrm{w}$ postaci obniżenia majątkowego cenzusu wyborczego $(1882,1896)$ oraz wprowadzenia piątej kurii wyborczej dla wszystkich mężczyzn, którzy ukończyli 24. rok życia i co najmniej od 6 miesięcy zamieszkiwali w gminie głosowania (1896). Istotna zmianę wprowadziła dopiero ustawa z 26 I 1907 r., która zniosła podział wyborców na kurie przy wyborach do Rady Państwa. Sejm Krajowy po długiej walce uchwalił 14 II 1914 r. reformę ordynacji wyborczej. Zachowała ona zasady reprezentacji interesów (chociaż rozszerzyła prawa wyborcze na grupy ludności, które ich dotąd nie posiadały) oraz reprezentacji narodów (w przypadku Galicji polskiego i ukraińskiego). Nie weszła jednak w życie z powodu wybuchu I wojny światowej.

Prawo wyborcze do rad gminnych oparte było na kryterium opłacania podatków bezpośrednich $\mathrm{w}$ gminie lub kryterium wykształcenia, a wyborcy podzieleni byli na trzy koła wyborcze. Głosowanie było jawne,

${ }^{77}$ Kilka uwag o „Towarzystwie Szkoty Ludowej”, „Mieszczanin” 1895, nr 7, s. 106-107; Kilka słów gorzkiej prawdy, „Mieszczanin” 1907, nr 15-16, s. 2-3. 
ponieważ tajne musiałoby mieć formę pisemna, a ze względu na wysoki poziom analfabetyzmu w Galicji trudno byłoby je przeprowadzić. Jawność miała też umożliwić wyborcom kontrolę nad czynnościami komisji wyborczych. W praktyce jednak stwarzało to okazję do wywierania presji na wyborcach poprzez zawoalowane formy przekupstwa (tzw. kiełbasa wyborcza) lub zastraszanie ${ }^{78}$.

Były też inne okazje do nadużyć wyborczych. Za niewłaściwe pismo uważało obsadzanie wysokich stanowisk w kasach zaliczkowo-oszczędnościowych radnymi, którzy dzięki temu zyskiwali wpływy w lokalnej społeczności, co wykorzystywali przy kolejnych wyborach. Sama idea towarzystw zaliczkowych i kredytowych była według „Mieszczanina” dobra, ale jej wprowadzanie w życie już niekoniecznie. Pismo wskazywało, że instytucje te prawie nie podlegają kontroli rządowej, a metody ich działania przywodzą niekiedy na myśl lichwę, przynajmniej w zakresie narzucania klientom własnych warunków. Uznanie natomiast znalazły kasy Raiffeisena, które działały, opierając się nie tylko na przesłankach ekonomicznych, ale także ideach solidaryzmu ${ }^{79}$.

Społeczność żydowska z racji swojej pozycji zajmowanej w życiu gospodarczym była blisko związana z przedstawicielami większej własności, a poprzez nich także $\mathrm{z}$ aparatem administracyjnym państwowym i samorządowym. „Mieszczanin” zarzucał Żydom, że głosują według wytycznych kahału lub daja się przekupić oraz że ulegają wpływom ruchu socjalno-demokratycznego. Odgrywali też według pisma szkodliwą rolę, wpływając na decyzje wyborców poprzez demagogię lub presję. Mimo tych zastrzeżeń nie odżegnywano się całkowicie od społeczności żydowskiej. Drobnych przemysłowców żydowskich, zarabiających praca własnych rąk i zadowalających się małym zyskiem, „Mieszczanin” określał jako „względnie najzdrowszy czynnik" ${ }^{\circ 0}$, apelowano, by żydowscy wyborcy byli solidarni z polskim mieszczaństwem, a mimo kolejnych rozczarowań wynikami wyborów i postawą wyborców żydowskich pismo wzywało za Juliuszem Słowackim: „Niech żywi nie tracą nadziei”"1.

${ }^{78}$ Historia państwa i prawa Polski..., t. 4, s. 274-278, 283-288, 312-324; zob. też J. Hoff, Społeczność małego miasta galicyjskiego..., rozdz. Życie polityczne, s. 122-143.

${ }^{79}$ Ludzie - czy szakale?, „Mieszczanin” 1904, nr 9, s. 2-3; Banki lichwiarskie, „Mieszczanin” 1904, nr 13, s. 2-3; Nasze kasy zaliczkowe i oszczędnościowe, „Mieszczanin” 1907, nr 2, s. 1-3; zob. też G. Zamoyski, „Pracuj i oszczędzaj”. Kasy Oszczędności $w$ Galicji w latach 1844-1914, Rzeszów 2013; A. Zakrzewski, Od Stojałowskiego do Witosa, Warszawa 1988 (Dzieje Narodu i Państwa Polskiego, III-53), s. 49-50.

${ }^{80}$ Kafar, Zkwestyi żydowskiej. (Dokończenie), „Mieszczanin” 1895, nr 18, s. 276-277.

${ }^{81}$ Przed walka, „Mieszczanin” 1897, nr 4, s. 1; J.L. Jastrzębiec, Rola Żydów galicyjskich w agitacyi wyborczej, „Mieszczanin” 1897, nr 6, s. 3-4; Obywatele - wyborcy!, „Mieszczanin” 1908, nr 5, s. 1-2; Żydowski poset, „Mieszczanin” 1908, nr 5, s. 1-2; nr 6, 


\section{Wzrost aktywności politycznej mieszczan przed wyborami}

Przed wyborami wzrastała aktywność polityczna wszystkich partii i stronnictw. W 1904 r. „Mieszczanin” pisał: „Budzą się miasta” ${ }^{22}$, informując o zawiazzaniu przez obywateli Bochni towarzystwa politycznego, którego zasady wzorowane były na demokratycznych. Jako cel pismo stawiało: „Wydobycie się z poniżającej niewoli kacyków i wywalczenie lepszego dobrobytu" ${ }^{83}$. Sukcesem było pojawienie się niezależnych komitetów wyborczych oraz mieszczańskich kandydatów, i to niekiedy w opozycji do uznanych osobistości ze świata polityki (jak np. w Stanisławowie, gdzie w 1908 r. w wyborach do Sejmu Krajowego były burmistrz Leon Biliński współzawodniczył z wysuniętym przez mieszczaństwo miejscowym obywatelem Antonim Zajaczkiem, ostatecznie z sukcesem ${ }^{84}$.

Niepowodzenia wyborcze były przykre, ale wyciagano z nich wnioski. „Mieszczanin” wskazywał na braki organizacyjne, zalecał przyjmowanie programu stronnictwa ludowego lub demokratycznego, nieogladanie się na inteligencję ${ }^{85}$. Redakcja oceniała ją bowiem krytycznie, zarzucając „niski poziom umysłowy i kulturalny, brak samodzielności, zbiurokratyzowanie, gburowatość i łapczywość na pensyjki i awanse”. Żydom czyniono wymówki, że związani interesami z inteligencja, „oddali się do dyspozycji kliki rządzącej”, ale dostrzegano też docieranie prądów demokratycznych do tej grupy ${ }^{86}$. Co najistotniejsze jednak, winy doszukiwano się przede wszystkim w postawie samego mieszczaństwa: „wszystko złe, jakie obecnie widzimy w naszych miastach, myśmy sami spowodowali naszą obojętnością i nieporadnością"87. I nieustająco nawoływano: „Do roboty...!”88.

s. 2-4, cyt. ze s. 2. Tematykę żydowską zob. też: Rogatki, myta, czyli szlabanty, „Mieszczanin” 1894, nr 6, s. 90; Jak się zapatrujemy na kwestye semicka?., „Mieszczanin” 1895, nr 2, s. 17-19; Popierajmy nasz przemyst!, „Mieszczanin” 1895, nr 4, s. 49-50; Zapatrywanie Watykanu na antysemityzm, „Mieszczanin” 1895, nr 4, s. 125-126; Gtos kupca $w$ sprawie swojskiego handlu, „Mieszczanin” 1895, nr 14, s. 216-217; Na kim opierać się powinno nasze mieszczaństwo?, „Mieszczanin” 1895, $\mathrm{nr} 15, \mathrm{~s} .225 ; Z$ kwestyi żydowskiej, „Mieszczanin” 1895, nr 16, s. 247-249; nr 17, s. 261-262; Żydzi w dawnej Polsce, „Mieszczanin” 1897, nr 8, s. 4; Brońmy się!, „Mieszczanin” 1897, nr 20, s. 3.

${ }^{82}$ Budza się miasta, „Mieszczanin” 1904, nr 24, s. 1-2.

${ }^{83}$ Obywatele! Wyborcy!, „Mieszczanin” 1907, nr 10, s. 1.

${ }^{84}$ Zob. też S. Grodziski, Sejm Krajowy galicyjski 1861-1914, Warszawa 1993.

${ }^{85}$ Na dzień 23 maja 1907, „Mieszczanin” 1907, nr 10, s. 3-4; Rozmyślania na czasie, „Mieszczanin” 1907, nr 13-14, s. 1-2; Kronika, „Mieszczanin” 1908, nr 4, s. 6.

${ }^{86}$ Inteligencya $i \dot{z} y d z i$ wobec naszego mieszczaństwa, „Mieszczanin” 1908, nr 9, s. 1-2.

${ }_{87}$ Nie bójcie się...!, „Mieszczanin” 1908, nr 14-15, s. 1-2.

${ }_{88}$ Do roboty...! (Apel do Mieszczaństwa miasta N. Sacza), „Mieszczanin” 1908, nr 9 , s. 3 . 


\section{Zakończenie}

„Mieszczanin” pojawił się na rynku wydawniczym Galicji w $1894 \mathrm{r}$. i z przerwami funkcjonował do 1908 r., czyli przez 14 lat. Był to ważny czas w życiu społecznym, wówczas kształtowały się bowiem nurty polityczne, powołując do życia organizacje polityczne i wydając własne organy prasowe. Takie też zadanie postawiła sobie redakcja pisma doprowadzenie do przebudzenia społecznego i politycznego mieszczan, co zaowocować miało utworzeniem własnego stronnictwa. Cel ten został osiagnięty tylko częściowo. Odrębne stronnictwo mieszczańskie nie powstało, ponieważ mieszczaństwo było zbyt słabe pod względem gospodarczym i na poziomie świadomości społecznej, jego najlepiej wykształcona i aktywna część, czyli inteligencja, ciążyła raczej ku warstwie szlacheckiej i wyższej urzędniczej, nierzadko zapominając o swoim mieszczańskim i chłopskim rodowodzie, nie czuła natomiast związku z drobnomieszczaństwem, wreszcie lepiej rozwinięty ruch ludowy i demokratyczny przyciagały bardziej przedsiębiorcze jednostki, dając im większe możliwości działania w swoich istniejących już strukturach. Na próby zmiany dotychczasowego układu sił na scenie politycznej Galicji niechętnie patrzyli też ci, którzy do tej pory odgrywali w nim decydujaça rolę, czyli szlachta, powiązana siecią interesów i kontaktów towarzysko-rodzinnych z wyższymi urzędnikami, duchowieństwem, inteligencja. Działalność publicystyczna „Mieszczanina” przyniosła jednak zmiany w postrzeganiu rzeczywistości przez mieszczaństwo. Najważniejsze było przekonanie, że istniejący stan rzeczy można i należy zmienić, ale nie stanie się to samo, lecz dzięki staraniom samych zainteresowanych. Pismo wykonało wielką pracę, kształtując poczucie odrębności mieszczaństwa, dumę z zasług tego stanu dla Rzeczypospolitej, a także postawy obywatelskie poprzez informowanie o uwarunkowaniach prawnych obowiązujących w różnych dziedzinach życia i możliwościach działania, jakie daja obywatelom. Propagowano także charakter i cnoty moralne ułatwiające podniesienie ekonomicznego poziomu życia i poszerzenie perspektywy postrzegania świata oraz praktyczne umiejętności w zakresie znajomości prawa, stosunków szkolnych, prowadzenia gospodarstwa, leczenia domowymi środkami. O dokonanych przemianach świadczyły zakładane stowarzyszenia o charakterze gospodarczym, oświatowym, kulturalnym, a także bardziej świadome angażowanie się $\mathrm{w}$ wybory, co niekiedy przynosiło pożądane rezultaty w postaci tworzenia własnych komitetów wyborczych czy wystawiania własnych kandydatów. Podziw budzi energia, wytrwałość i optymizm obu redaktorów „Mieszczanina”, którzy nie ustawali w wysiłkach 
i realizacji zamierzonych planów, chociaż efekty pracy widoczne były dopiero z dłuższej perspektywy. Mimo trudnych nieraz okoliczności stali na stanowisku: „Wierzymy silnie, wierzymy gorąco, że wytrwałość w dobrem dziele musi obudzić uśpione umysły, musi wskrzesić zapał, energię i odwagę dla wzniosłych i szlachetnych ideałów" 89.

\section{Bibliografia}

„Mieszczanin” 1894-1895, 1897, 1903-1908

Aleksander T., Życie społeczne i przemiany kulturalne Nowego Sqcza w latach 1870-1990, Kraków 1993.

Broński K., Miasta galicyjskie we wspótczesnej historiografii. Przeglad badań i problemów, w: Pamięć, wybór, tożsamość. Szkice o mieście, red. K. Broński, R. Kusek, J. Sanetra-Szeliga, Kraków 2016, s. 25-47.

Franaszek P., Kluczowe zagadnienia dziejów gospodarczych Galicji, w: Galicja. Studia $z$ dziejów spoteczno-gospodarczych, red. M. Baczkowski, T. Kargol, Kraków 2017, s. 67-82.

Gąsowski T., Galicja - „żydowski matecznik”, w: Galicja i jej dziedzictwo, t. 2: Społeczeństwo i gospodarka, red. J. Chłopecki, H. Madurowicz-Urbańska, Rzeszów 1995, s. 125-134.

Jarowiecki J., Kształtowanie się środowiska prasowego Nowego Sqcza i regionu, w: Prasa sadecka od zarania do dziś 1891-2011, red. B. Faron, współpr. A. Ogonowska, Kraków 2012, s. 9-27.

Kwaśniewicz W., Między modelem agrarnym a postindustrialnym. Przeobrażenia spoleczeństwa polskiego $w$ XX wieku, w: Polska i Polacy $w$ XIX-XX wieku. Studia ofiarowane Profesorowi Mariuszowi Kulczykowskiemu w 70. rocznice jego urodzin, red. K. Ślusarek, Kraków 2002, s. 135-145.

Lewicki W., Organizacja gmin miejskich w Galicji, „Ekonomista Polski” 5, 1891, s. 36-56, 295-311.

Miodunka P., Demograficzny i gospodarczy potencjat matych miast potudniowej Polski od końca XVI do poczatku XIX wieku, RDSG, t. 78, 2017, s. 131-161.

Rejman S., Działalność samorzqdów gminnych w zakresie bezpieczeństwa $i$ porzqdku publicznego $w$ znaczniejszych miastach zachodniogalicyjskich w latach 1889-1914, Rzeszów 2013.

Rejman S., Samorzad miejski w okresie autonomii galicyjskiej i II RP - ciqgtość $i$ zmiana, w: Kulturotwórcza rola samorzadów terytorialnych. Historia - wspótczesność - perspektywy, red. Z. Lenart, M. Menz, Warszawa 2018, s. 55-77.

Weinfeld I., Ludność miejska Galicji i jej skład wyznaniowy (1881-1910), Lwów 1912 (Wiadomości Statystyczne o Stosunkach Krajowych, 24/2).

${ }^{89}$ Prośba do naszych Przyjaciót, „Mieszczanin” 1905, nr 10, s. 1. 
Zamoyski G., „Pracuj i oszczędzaj”. Kasy Oszczędności w Galicji w latach 1844-1914, Rzeszów 2013.

Żarnowski J., Historia spoteczna. Metodologia, ewolucja, perspektywy, Warszawa 2011 (Metamorfozy Społeczne, 3).

Sabina Rejman

Attempts to stimulate socio-political activity in towns in the era of the autonomy of Galicia (on the example of the Mieszczanin)

(Summary)

In the second half of the nineteenth century, traditional and emerging socio-political movements started to form their own political organizations, develop programs, and issue press publications. One of the groups to look for its unique identity was the internally divided bourgeoisie. The intelligentsia, despite its members often hailing from a bourgeois or peasant background, had higher social aspirations. They refused to perform the role of the leaders of the bourgeoisie. The petty bourgeoisie was consumed by the struggle to compete against imported foreign production and Jewish merchants and manufacturers. Jews, having long constituted a large percentage of the population of towns, continued to retain a separate cultural identity. The Autonomy of Galicia brought new opportunities to the bourgeoisie, but they were hardly taken advantage of. The Mieszczanin, a magazine published in Nowy Sacz in the years 1894-1908 (with interruptions) and edited by Józef Gutowski and Zygmunt Mayer, took it upon itself to change the situation. The publication discussed everyday issues of town dwellers, including the municipal government, economy, law, societal issues, elections. It avidly supported all forms of social activity, especially those carried out in an organized fashion. However, no bourgeois party was ever established. The bourgeoisie was too weak, internally divided, and susceptible to the influences of existing political parties. The goal of converting the burghers into a social group aware of its separate character, politically active, economically strong, and committed to the values of industriousness and frugality, was never fully achieved. The activity of the magazine did render some results, but some of its aims were impossible to be brought to fruition, and the societal transformations were hampered by the outbreak of World War I.

Sabina Rejman - dr hab., pracownik Instytutu Historii Uniwersytetu Rzeszowskiego. Jej zainteresowania badawcze koncentrują się wokół Galicji: zagadnienia demograficzne i społeczne, funkcjonowanie samorządu w miastach Galicji Zachodniej, historia regionalna. 
Sabina Rejman - PhD with habilitation, member of the Institute of History, University of Rzeszów. Her academic interests focus on Galicia: demographic and social issues, operation of local government in the towns of Western Galicia, regional history.

E-mail: srejman@post.pl. 